Ayurlog: National Journal of Research in Ayurved Science

\title{
Role of vikarvighatbhava and vikarvighatabhava in manifestation of diabetes
}

\section{Goray Namrata Prakash*1, Harit Maheshkumar ${ }^{2}$, Vinay Pawar ${ }^{3}$}

1. P.G scholar, Dept. of Sanskrit Samhita,

2. Dean and Professor,

3. Assistant Professor,

Dept. of Sanskrit Samhita Siddhant School of Ayurveda,

D. Y. Patil University, Nerul, Navi Mumbai, Maharashtra.

* Corresponding author: Contact: 9867967225, email: vd.namratagoray@ gmail.com

Abstract:

Background: The consequence of variation in ecological factors, intensity of the morbid humors and susceptibility of the body elements influences suppression or incidence of the disease by Vikar vighat bhava and Vikar vighat abhave respectively. Owing to the occurrence pathological changes, along with vitiation of morbific factor like, increased kleda (excessive fluidity) and shithilata (diminished viscous essential) and due to frequent indulgent etiological factors, the body fluid, combined with humors and adipose tissue, acquires the pathological character of Prameha(diabetes).

Objective: The present study was done to conceptualize the role of Vikar vighat bhava and Vikar vighat abhava in resistance and development respectively, of Prameha with all its symptoms.

Methods: Conceptual literary search done by referring literature on exercise, Ayurveda texts, and research papers from peer-reviewed journals to explore the role of Vikar vighat bhava and Vikar vighat abhava in manifestation and therapy of Prameha.
Result: The vikar vighat abhava like avoidance of exercise, swapnasukha (sleeping for long hours), asyasukha (sedentary life style) and kaphakar aahar (diet increasing and vitiating kapha) leads Aghnimandya (decreased digestive power and metabolism) which is the reason for besity, hyperlipidemia and development of insulin resistance. Whereas Vikar vighat bhava like losing weight, optimal diet and exercise regime, helps to reduce insulin resistance and prediabetes, thus preventing or delaying type 2 diabetes.

Conclusion: The Vikar vighat bhava like strict diet i.e Ystvaharam sharirasyadhatusamyakarm and daily exercise i.e sevate vividhanschy anyacheshtah can keep check on the diabetes. The dietary and exercise regime along with increase in immunity will help more in pre diabetic conditions.

Key words: Vikar vighat bhava, vikar vighat abhava, prameha.

\section{INTRODUCTION:}

The etiology of diabetes in India is multifactorial and includes genetic factors 
coupled with environmental influences such as obesity associated with rising living standards, steady urban migration, and lifestyle changes. Food insecurity, illiteracy, poor sanitation ${ }^{[1]}$ and dominance of communicable diseases may all contribute, threat of diabetes. Obesity is one of the major risk factors for diabetes, despite having lower, overweight and obesity rates, India has a higher prevalence of diabetes compared to western countries, Indians are genetically predisposed to the development of coronary artery disease due to dyslipidemia and low levels of high density lipoproteins; these determinants make Indians more prone to development of the complications of diabetes at an early age (20-40 years) and indicate that diabetes must be carefully screened and monitored regardless of patient age within India.

Significant changes in the life-style ar observed with every passing decade. Wit increase in the number of newly diagnosed diseases some diseases are been troublesome since ancient times, for e.g. Madhumeha (diabetes), Raktagata Vata (Hypertension),

Rajayakshma (tuberculosis), Arbuda (Cancer), Shwas (Asthma) etc. But they were kept well controlled by proper diet, exercise and behaviour. With the passing time, in spite of having advanced tools and technology for the detection and management of disease, these troublesome diseases are changed to gruesome diseases due to improper management of diet, exercise and behaviour.

In the context of, various current, health problems, leading to impairment of immune system; it becomes the need of a time to study the ancient concept of Vikar vighat bhava and Vikar vighat abhava to ameliorate the immune system.
The present study was done to conceptualize the role of Vikar vighat bhava and Vikar vighat abhava in resistance and development respectively, of Prameha with all its symptoms.

How does dietary and exercise regime along with increase in immunity help more in pre diabetic conditions and insulin resistance.

\section{MATERIALS AND METHODS:}

Conceptual literary search done by referring literature on exercise, Ayurveda texts, and research papers from peerreviewed journals to explore the role of Vikar vighat bhava and Vikar vighat abhava in manifestation and therapy of Prameha. Discussion was made according to the conceptual study, and conclusion were drawn in accordance with the conceptual study and discussion.

\section{Conceptual study:}

Modern scientist classify Prameha i.e Diabetes in a group of disease called Metabolic Syndrome. Metabolic syndrome is also called Insulin resistance syndrome. It is group of traits and medical condition linked with overweight and obesity.

For a person to be defined as having the Metabolic Syndrome [2], he must have central obesity plus any two of four additional factors.

These four factors are:

- Raised TG level: $\geq 1.7 \mathrm{mmol} / \mathrm{l}(150$ $\mathrm{mg} / \mathrm{dl}$ )

- Reduced HDL-cholesterol: < 1.03 $\mathrm{mmol} / \mathrm{l}(40 \mathrm{mg} / \mathrm{dl})$ in males and $<1.29$ $\mathrm{mmol} / \mathrm{l}(50 \mathrm{mg} / \mathrm{dl})$ in females (or specific treatment for these lipid abnormalities)

- raised blood pressure (systolic $\mathrm{BP} \geq 130$ or diastolic $\mathrm{BP} \geq 85 \mathrm{mmHg}$ ) (or treatment of previously diagnosed hypertension)

- raised fasting plasma glucose $[\mathrm{FPG} \geq 5.6$ $\mathrm{mmol} / \mathrm{l} \quad(100 \mathrm{mg} / \mathrm{dl})]$ (or previously diagnosed type 2 diabetes) 
Ayurveda says all diseases are result of Aghnimandya [3] (metabolic disorder) which can be due to various causes divided into two major groups Santarpanjanya and Apatarpanjanya. ${ }^{[4][5]}$

The list of disorders under Santarpanjanya vyadhi are Prameha, diabetic boils, urticarial patches, itching, anemia, fever, leprosy, disorders due to Ama, dysuria, anorexia, drowsiness, impotency, overobesity, lassitude, heaviness in body, obstruction in sense organs and channels, disorders of consciousness, sleepiness, swelling, disorders of flatus, leprosy, piles, jaundice, spleen (enlargement), anemia, swelling, dysuria, anorexia, heart disease, phthisis, cough, dyspnea, choking of throat, helminthiasis, leukoderma, over obesity and similar other disorders ${ }^{[6]}$. Disorders due to Meda Dhatu dushti are the despicable ones and the premonitory symptoms of Prameha ${ }^{[7]}$.

Insulin resistance which is the major caus of metabolic syndrome is the condition in which muscle, fat and liver cells do not respond properly to insulin and thus does not allow the easy absorption of glucose from blood stream. As a result body requires higher amount of insulin to help glucose enter into the cells.

The Beta cells of pancreas try to keep up with the increased demand by producing more. But over a period these over stressed cells stop functioning thus leading to prediabetic and /or diabetic condition ${ }^{[8]}$.

Ayurveda describes this as Aghnimandya leading to Strotorodha (cell resistance to insulin) leading to Kledotpatti and Dhatu shaithiya ( ) which is the cause of Aapachit, Asara Dhatu nirmiti due to Dhatvaghni Mandya (improper cellmetabolism, improper or less absorption of sugar) causing Prameha (Polyuria, polydipsia and polyphagia). The condition wherein demand and production of Insulin is not matched pre-diabetic conditions are seen as Purvarupa of Prameha ${ }^{[9]}{ }^{[10]}$.If proper diet and exercise regime is not followed in this condition it leads to Prameha ${ }^{[12]}$ i.e Type 2 Diabetes ${ }^{[11]}$.

In this condition right from beginning Vikar vighat bhava play important role in proper control at pre-diabetic level and delaying the onset of type 2 diabetes, by developing Vyadhiksamatva.

'Vyadhiksamatva' means preventive response of subject to the disease. It can be correlated to the concept of immunity. In the context of above mentioned metabolic syndrome; it becomes the need of a time to study the ancient concept of Vikar vighat bhava and Vikar vighat abhava to ameliorate the immune system. These are described as Doshadushyavisheshebhyo vikarvighatbhavabhav in Charak idansthana Pramehanidanadhyaya. We ind that the consequence of variation in ecological factors, intensity of the morbid humors and susceptibility of the body elements influences suppression or incidence of the disease by Vikar vighat bhava and Vikar vighat abhava respectively.

The frequent indulgent causes like kaphakar aahar (diet increasing and vitiating kapha), avoidance of cleanliness, divaswaap (sleeping in afternoon), swapnasukha (sleeping for long hours), asyasukha (sedentary life style) and other factors which increase kapha, meda (fat), mutra (urine) are all special etiological factors, and due to frequent indulgent etiological factors, the body fluid, combined with humors and adipose tissue, acquires the pathological character of Prameha (diabetes). Here the Vyadhikshamatva in the form of Vyadhibala virodhitvam (dwindling of 
manifested disease) and Vyadhi utpad pratibandhakatvam (avert the manifested one) gives us idea that the Vikar vighat bhava helps one to resist the disease.

The components required for manifestation of disease are Nidana, Dosha and Dushya. Nidana is the bahya hetu (external cause) while Dosha and Dushya are aabhyantar hetu (internal cause). We know that Dosha and Dushya have ashraya-ashrayee bhava, so when external factors vitiate the Dosha and Dushya also get vitiated and their amalgamation leads to manifestation of disease. When treatment is planned reverse is done, first the external factors are removed, then amalgamation is broken and then the vitiated Doshas are brought under normal level.

Sometimes even in the presence of Nidana, Dosha and Dushya disease does not manifest. This resistance to disease due to Vikara Vighata Bhava. ${ }^{[13]}$

\section{इह खलु निदानदोषदूष्यविशेषेभ्यो विकारविघातभा} वाभावप्रतिविशेषा भवन्ति|

यदा ह्येते त्रयो निदानादिविशेषाः परस्परं नानुबधन्त्य थवा कालप्रकर्षादबलीयांसोऽथवाऽनुबध्नि्ति न तदा विकाराभिनिर्वृत्तिः,चिराद्वाडप्यभिनिर्वर्तन्ते, तनवो वा भवन्त्ययथोक्तसर्वलिड़ग वा; विपर्ययेविपरीताः; इतिस वविकारविघातभावाभावप्रतिविशेषाभिनिर्वृत्तिहेतुर्भव त्युक्तः च. नि $४ / ४$

By practicing Vikara Vighata Bhava [12] there arises four possibilities like a) Vikara janana- no occurrence of disease. b) Chirena Vikara janana- late occurrence of disease. c) Annu Vikarjanana- occurrence of disease in subtle form or mild. d) Asarvalinga Vikara janana- occurrence of disease with less symptoms or the symptoms are not properly manifested. If Nidana (external) is taken, but it is not able to interact with Dosha then the disease does not occur (Vikarajanana). When the Nidana is of less intensity, and if Vyadhikshamatva is normal, then the amalgamation of Hetu with Dosha and Dushya occurs with passage of time. Here, the disease does not occur. But, again if the same etiological factors are taken then it vitiates the Doshas, as they are already weak due to previous manifestation. The disease occurs after a period of time.

Out of different types of Hetus mentioned one is Vyabhichari Hetu, which means the cause is not potent enough to produce a disease. Similarly in the context of Abhesaja two types are mentioned Badhana and Sanubadhana. The Sanubadhana is one such in which the cause is present inside body and disease occurs after a longer time. In the condition mentioned Vyabhichari Hetu and Sanubadhana type of Abhesaja can be inferred. Just opposite to it is the, Vikara Vighata Abhava .That means occurrence of disease is rapid, with manifestation of all symptoms. Etiological factors having homologous properties as Dosha interact with them quickly leading to manifestation or aggravation of disease i.e. Vikara Vighata Abhava

Table no-1 Vikara Vighata Abhava and Disease:

\begin{tabular}{|l|l|}
\hline $\begin{array}{l}\text { Vikara Vighata } \\
\text { Abhava }\end{array}$ & Disease \\
\hline $\begin{array}{l}\text { Divaswaap, } \\
\text { Asyasukha }\end{array}$ & Prameha \\
\hline $\begin{array}{l}\text { Excessive intake } \\
\text { of kshara }\end{array}$ & Rakta-Pitta \\
\hline $\begin{array}{l}\text { Fasting, } \\
\text { swimming }\end{array}$ & Sandhigata Vata \\
\hline
\end{tabular}


Table no-2 Vikara Vighata Bhava-abhava in relation with Vyadhikshamatva and occurrence of disease:

\begin{tabular}{|l|l|l|l|l|}
\hline $\begin{array}{l}\text { Vikara Vighata } \\
\text { bhava -abhava }\end{array}$ & Vyadhikshamatva & $\begin{array}{l}\text { Status of } \\
\text { amalgamation }\end{array}$ & \multicolumn{2}{|c|}{ Occurrence of disease } \\
\hline $\begin{array}{l}\text { Vikara Vighata- } \\
\text { abhava }\end{array}$ & Low & Fast & $\begin{array}{l}\text { Fast } \\
\text { occurrence }\end{array}$ & Vikarotpatti \\
\hline \multirow{4}{*}{$\begin{array}{l}\text { Vikara Vighata } \\
\text { Bhava }\end{array}$} & \multirow{2}{*}{ Vital } & No interaction & No disease & Vikarajanana \\
\cline { 3 - 5 } & $\begin{array}{l}\text { Interaction } \\
\text { with passage } \\
\text { of time }\end{array}$ & $\begin{array}{l}\text { Late } \\
\text { occurrence }\end{array}$ & $\begin{array}{l}\text { Chirena Vikara } \\
\text { janana }\end{array}$ \\
\cline { 3 - 5 } & $\begin{array}{l}\text { Interaction in } \\
\text { subdued form }\end{array}$ & $\begin{array}{l}\text { Few \& } \\
\text { subtle } \\
\text { symptom }\end{array}$ & $\begin{array}{l}\text { Annu } \\
\text { Vikarjanana }\end{array}$ \\
\cline { 3 - 5 } & Interaction \\
exists & $\begin{array}{l}\text { occurrence } \\
\text { of disease } \\
\text { with un- } \\
\text { manifested } \\
\text { symptoms }\end{array}$ & $\begin{array}{l}\text { Asarvalinga } \\
\text { Vikara janana }\end{array}$ \\
\hline
\end{tabular}

Table no-3 Vikar vighat bhava janya Vyadhikshamatva and its action

\begin{tabular}{|l|l|l|l|}
\hline Nidan & Prabhava & \multicolumn{2}{|c|}{ Occurrence of disease } \\
\hline \multirow{5}{*}{$\begin{array}{l}\text { Vikar vighat bhava janya } \\
\text { Vyadhikshamatva }\end{array}$} & $\begin{array}{l}\text { Vyadhiutapada } \\
\text { pratibandhakatvam }\end{array}$ & Vikarajanana & $\begin{array}{l}\text { No occurrence of } \\
\text { disease }\end{array}$ \\
\cline { 2 - 4 } & \multirow{4}{*}{$\begin{array}{l}\text { Vyadhibala } \\
\text { virodhitatvam } \\
\text { janana }\end{array}$} & $\begin{array}{l}\text { Late occurrence of } \\
\text { disease }\end{array}$ \\
\cline { 3 - 4 } & Annu Vikarjanana & $\begin{array}{l}\text { Occurrence with few } \\
\text { symptoms }\end{array}$ \\
\cline { 2 - 4 } & $\begin{array}{l}\text { Asarvalinga } \\
\text { Vikara janana }\end{array}$ & $\begin{array}{l}\text { Occurrence with } \\
\text { un-manifested } \\
\text { symptoms }\end{array}$ \\
\hline
\end{tabular}

The above information leads us to the concept of Vikar vighat bhava is nothing but Nidan Parivarjan and Vikar vighat abhava is Hetu sevan which leads to resistance to disease or manifestation of disease respectively. Diabetes is complex and its intricate mechanisms can be subtly manipulated by diet and exercise regime. According to medical scientists Vikar vighat bhava i.e Physical and mental cleansing and strengthening therapy is successful because of the balance created in the nervous system and endocrine system which influence all other systems 
and organs of the body. Instead of treating the disease, it eliminates the causative factors ${ }^{[14]}$ this is Nidan Parivarjan.

The exciting part about the new science of genomics or especially nutrigenomics as stated by Dr. Vincent Belzoni "that you can change who you are, by how you treat your genes in terms of changing the nutrients that we expose our genes to. Since it is not hard wired, it is truly up to us to make the choice between choosing to take care by ourselves, as opposed to be taken care by someone else and thus prevent the disease called diabetes, essentially created by wrong lifestyle ${ }^{[15]}$.With proper exercise patients develop a sense of wellbeing with lowering of dosage of drugs and diminished incidence of acute complications like infection and ketosis. Significant changes in the insulin kinetics and those of counter-regulatory hormones like cortisol are seen. The fall is free fatty acids suggests better insulin sensitivity and decrease in insulin resistance. There is a beneficial effect on the co-morbid conditions ${ }^{[16]}$. Stress is also one of the leading cause of insulin resistance. The hyperinsulinemia can be either due to down regulation of insulin receptors as observed in obesity or increased sympathetic activity as observed in altered cardiac autonomic function ${ }^{[17]}$.

\section{THE VIKAR VIGHAT ABHAVA WHICH PLAY IMPORTANT ROLE IN MANIFESTATION OF DIABETES: [18] [19] [20]}

Kaphakar aahar (diet increasing and vitiating kapha), avoidance of cleanliness, divaswaap (sleeping in afternoon), swapnasukha (sleeping for long hours), asyasukha (sedentary life style) and other factors which increase kapha, meda (fat), mutra (urine). Excess weight, obesity, hyperlipidemia, physical inactivity primary cause of insulin resistance.

Excess weight: obesity: hyperlipidemia: It was believed that fat tissue functioned solely as energy storage. However, studies have shown that belly fat produces hormones and other substances that can cause serious health problems such as insulin resistance, high blood pressure, imbalanced cholesterol, and cardiovascular disease (CVD).

Belly fat plays a part in developing chronic, or long-lasting, inflammation in the body. Chronic inflammation can damage the body over time, without any signs or symptoms. Scientists have found that complex interactions in fat tissue draw immune cells to the area and trigger lowlevel chronic inflammation. This inflammation can contribute to the development of insulin resistance, type 2 iabetes, and CVD. Studies show that losing the weight can reduce insulin resistance and prevent or delay type 2 diabetes.

Excess Weight: Physical Inactivity: Many studies have shown that physical inactivity is associated with insulin resistance, often leading to type 2 diabetes. In the body, more glucose is used by muscle than other tissues. Normally, active muscles burn their stored glucose for energy and refill their reserves with glucose taken from the bloodstream, keeping blood glucose levels in balance. But when a person is physically inactive even though the stored glucose is not burned to get energy it is regularly refilled. This causes the stimulation for extra insulin secretion for managing the blood glucose levels. The hyperinsulinemia can be either due to down regulation of insulin receptors as observed in obesity or increased sympathetic activity as observed 
in altered cardiac autonomic function. Which stresses Pancreas, develops insulin resistance causing imbalance and losing homeostasis ${ }^{[21]}$.

Stress: The response of an individual to an external or internal stimuli causing difficulty in coping up with the situation is called stress. The attitude to life influences the very important section of brain called hypothalamus, which exercises control over major internal organs. It is considered as major functional link between body and mind. Increased stress vulnerability and other pathological and inappropriate stress coping behaviours causes emotional disturbances and sympathetic arousal leading to events that can trigger errors in metabolic pathways ${ }^{[22]}$.

\section{THE VIKAR VIGHAT BHAVA WHICH} PLAY IMPORTANT ROLE IN MANAGEMENT OF DIABETES ${ }^{[23][24}$ ${ }^{[25]}$ :

\section{OBESITY REDUCTION ${ }^{[26]}$ :}

a. Mitahara: nature has kept a great reserve everywhere. The corresponding physiological principle is that our appetite has been adjusted to a much higher level as compared to the need of the body. Therefore we can reduce the diet by half or even one-fourth of the felt appetite without losing a single kilo. So consume only half of what you have been eating every day. This reduces the caloric intake.

b. A weekly fast: Inducer of hormonesensitive lipase (HSL). It is a general principle of physiology that whatever organs/systems/biochemical pathways we use are maintained in good function. Whatever we don't use goes into atrophy. Therefore, there is reason to believe that those who never fast, lose their HSL. This explains their difficulty in fasting.
However, it is common observation that those who keep a regular weekly fast can tolerate it much better. This may be because their enzyme is in an induced state. The knowledge of physiology tells us that enzyme induction is detectable within 5 days and goes on till several weeks. Therefore when one starts observing a weekly fast, the sense of general weakness, 'sunkenness' etc all lasts for only 3-4 weeks. People should be given this explanation and encouraged to observe one weekly fast. In order to be really effective the fast should be observed taking only water and must be continued beyond 24 hours. It is then only that lipolysis starts. A clinical indicator is appearance of acetone in urine. This ensures that HSL has acted. Periodic Fasting for such duration should be recommended to keep the HSL in induced tate. To the obese patients, this serves as a key which can be operated at will as many times a week as required to lose desired weight.

c. Inverted asanas: Inverted asanas for 15-20 minutes: Atrial natriuretic peptide (ANP) releasers. The above mentioned HSL is acted upon by several hormones like thyroxine, adrenaline and glucagon. Recently, ANP has been found to do the same. That means anything that fills up and stretches the atria and stimulates release of ANP can be used for obesity. There are several asanas which invert the trunk and in this way cause increased atrial filling. They include shirshasana and sarvangasana.

d. Suryanamaskara: As described in the booklet 'Drink Air- Stay fit' it appears to be a series of manoeuvers designed to fill the intestines with air. In specified steps wherever the practitioner becomes upright, air is sucked into the stomach through the 
esophagus. Air distension of the gut is enough to create some satiety which makes it easy to stay without food for a day-long. There is reason to believe that this satiety is brought about by the release of GLP-1 which is a well-known intestinal satiety-peptide and has multitude of functions.

e. Aerobic activity ${ }^{[27]}$ : Aerobic exercise is the type of moderate-intensity physical activity in the presence of, or with, oxygen. that one can sustain for more than just a few minutes with the objective of improving ones cardiorespiratory fitness and health. Aerobic exercises that involve large muscle groups like walking, running and swimming also have health - promoting and therapeutic effect. The intensity of the exercise should be enough to produce 50$80 \%$ of maximum heart rate of the individual. Maximum heart rate calculated from the formula: HRmax 220 - (age x $0.5-0.8$ ) Exercise session should be for at least $30 \mathrm{~min}$ and on 4 or more days a week. Instead of $30 \mathrm{~min}$ on one day, one can have 3 sessions of $10 \mathrm{~min}$ each. Young men can do moderate or vigorous exercise, $60 \mathrm{~min}$ a day for at least 3 days a week. The benefits include lower risk of premature death, coronary heart disease, hypertension, type 2 diabetes mellitus and depression.

Studies show that after exercising, muscles become more sensitive to insulin, reversing insulin resistance and lowering blood glucose levels. Exercise also helps muscles absorb more glucose without the need for insulin. The more muscle a body has, the more glucose it can burn to control blood glucose levels ${ }^{[28]}$.

\section{REDUCTION OF CHOLESTEROL [29].}

a. Why the body synthesizes cholesterol? It has been studied that while our diet contains only $300 \mathrm{mg}$ of cholesterol, about $1100 \mathrm{mg}$ is excreted in the stool on a daily basis. All this cholesterol comes from the liver where it is synthesized and excreted in the stool. The purpose seems to be to prevent GI mucosal damage by enzymes, especially lipolytic and proteolytic ones. If we do not have digestive enzymes, we do not need cholesterol to protect our gut mucosa. So take predigested diet.

b. The protein myth: why do we require proteins in the diet? What for? It is a myth that we require to have protein in our diet. The fact is we require amino acids. These we require to build various structural and functional proteins which have different half -lives. The proteins synthesized once do not get destroyed quickly. There is only ne class of proteins that requires being synthesized every day and the whole quantity is destroyed the same day. These are the digestive enzymes secreted in the gut- the salivary and pancreatic amylase, pepsin, trypsin, chymotrypsin, lipase, and the host of different saccharides and peptidases. Studies have shown that an average person secretes about 60 grams of digestive enzymes in the gut. These cannot be reabsorbed as such and have to be broken down themselves into constituent amino acids. This way the maximum turnover of amino acids is for synthesis of digestive proteins. If we do not need to digest, we do not need to secrete digestive enzymes; so why not take predigested diet.

c. Fruit diet: Mostly dietary proteins are those synthesized by the plants or animals for their use. First we have to break them down into the component amino acids. Fruits contain lots of amino acids. Some of their sourness and sweetness is due to this. 
Fruits also contain absorbable sugars other than glucose which do not require insulin for their entry into cells. In addition, one gets electrolytes, vitamins and fiber from them.

\section{ACTIVATION OF BETA CELLS:}

a. Air - filling maneuvers as described above. Air distension of the gut produces satiety which is likely to be mediated by some satiety peptide. It can be Glucagonelike-peptide-1 (GLP-1) which is a known incretin and is also known to have anti apoptotic and beta cell stimulating action. Hypoxia stimulates proliferation of various kinds of cells in the body and can help migration of stem cells from other locations like bone marrow.

b. Methods to produce brief, intermittent hypoxia: As described elsewhere, several yogic practices lik bahya kumbhaka, nishshesha rechaka nauli and agnisara lead to brief hypoxia. Some asanas such as yogamudra and pawanmuktasana are also conducive to hypoxia.

c. A one-day-a-week fast: One day a week fast also increases survival of beta cells. Adipose cells, when saturated with fat secrete more of leptin and a number of 'Pro-inflammatory' cytokines. These lead to insulin resistance in the peripheral tissues. Some of these also deliver apoptotic signals to beta cells of the islets. No wonder, then, that a full 68 Proc Ntl Workshop -cum- Seminar on Yoga \& Diabetes $20 \%$ of the obese become diabetics. On the days of fasting, the adipose cells secrete much less of these chemicals, while the secretion of adiponectin increases. Adiponectin has anti-apoptotic, regenerative and proliferative effect on beta cells. In addition, on the day of fast, secretion of glucocorticoids is doubled. This can neutralize the effect of the proinflammatory cytokines, (without increase in blood glucose or blood pressure, as the individual is fasting). Therefore there is reason to believe that a periodic fast will go a long way in preventing diabetes in the obese. I have proposed a simple hypothesis, that a one-day fast postpones the onset of type- 2 diabetes by 6 days. This way, a non-diabetic person can stay away from diabetes by simply observing a one-day-a-week fast. Those with established diabetes who are still obese can undertake even 2-day-a-week fast, of course taking precautions to avoid hypoglycemia. It may require closer monitoring of blood glucose on the day of fast, and reduction of doses in hypoglycemic drugs.

\section{PREVENTION OF VASCULAR COMPLICATIONS:}

a. Hypoxia: Hypoxia is an inducer of nitric oxide synthase (NOS). So any of the methods described above to produce brief, intermittent hypoxia is suitable for treating vascular complications. Generation of nitric oxide is beneficial in hypertension, coronary artery disease and erectile dysfunction.

b. Asanas: Asanas activate peripheral vessels and nerves and have an effect due to remote ischemic preconditioning.

Result: The Vikar vighat abhava like avoidance of exercise, swapnasukha (sleeping for long hours), asyasukha (sedentary life style) and kaphakar aahar (diet increasing and vitiating kapha) leads Aghnimandya (decreased digestive power and metabolism) which is the reason for obesity, hyperlipidemia and development 
of insulin resistance. Whereas Vikar vighat bhava like losing weight, optimal diet and exercise regime, helps to reduce insulin resistance and prediabetes, thus preventing or delaying type 2 diabetes.

\section{Discussion:}

$>$ When any substance invades the body for manifestation of disease

$>$ Vyadhikshamatva becomes active.

- Vyadhikshamatva works by two methods, either the disease does not occur Vyadhi utpada pratibandhakatvam or,

- The body develops the strength to fight against the occurred disease Vyadhibala virodhitatvam.

$>$ Factors which resist the occurrence of disease are Vikara Vighata Bhava and,

$>$ The factors which facilitate th happening of disease are Vikara Vighata Abhava.

$>$ The Vyadhibala virodhitatvam is the outcome of Vikara Vighata Bhava.

○ This means the body is immune in such a way that it resists the abnormal things which are not good for body.

- Here the abnormal things are the Nidana which vitiate the dosha, and

$>$ Nidan Parivarjana is the first line of treatment of any disease.

$>$ The Sadhyasadhyatva of Prameha as stated by Acharya Charak gives us a clear idea that Prameha is Anushangi ${ }^{[30]}$ means Punarbhavi i.e it has family history because of Beeja Dosha ${ }^{[31]}$ and once a diabetic always a diabetic. It can be well controlled but not cured.

- The Vikar vighat bhava like strict diet i.e Ystvaharam sharirasyadhatusamyakarm [32] and,

- Daily exercise i.e sevate vividhanschy anyacheshtah [32] can keep check on the diabetes.

$>$ The dietary and exercise regime along with increase in immunity will help more in pre diabetic conditions.

\section{ACKNOWLEDGEMENT}

First and fore mostly I would like to express my deep and sincere gratitude to my research guide, Dr. Maheshkumar Harit Sir, Dean and Professor, Dept. of Sanskrit Samhita Siddhant School of Ayurveda, D Y Patil University, Nerul, Navi Mumbai, for giving me the opportunity to do research and providing invaluable guidance throughout this research. It was a great privilege and honor to work and study under his guidance.

My Special thanks goes to Vd. Vinay Pawar Sir for the keen interest shown to complete this research paper successfully. His dynamism, vision, sincerity and motivation have deeply inspired me. He has taught me the methodology to carry out the research and to present the research works as clearly as possible. I am extremely grateful for what he has offered me to complete the research successfully. I would also like to say thanks to Dr. Komal Gavali madam for her genuine support throughout this research work. I am extending my thanks to all my colleagues for their support during my research work. Finally, my thanks go to all 
the people who have supported me to complete the research work directly or indirectly.

\section{REFERENCES:}

1. Aghnivesh,Charak, Dridhabala, Chakrapanidatta, Charakasamhita, Nidan Sthana, Pramehanidan 4/50, edited by Jadavji Trikamji Acharya., Reprint edition, Chaukhambha Surabharati Prakashan Varansi,1992;215

2. Metabolic syndrome-a new world-wide definition. A Consensus Statement from the International Diabetes Federation K. G. M. M. Alberti, P. Zimmet* and J. Shaw* Department of Endocrinology and Metabolic Medicine, St Mary's Hospital, London, UK and *International Diabetes Institute, Caulfield. Australia, Accepted 19 Decembe 2005

3. Aghnivesh,Charak, Dridhabala, Chakrapanidatta, Charakasamhita, Chikitsa Sthana, Grahanidosha chikitsa 15/3-4, edited by Jadavji Trikamji Acharya., Reprint edition, Chaukhambha Surabharati Prakashan Varansi,1992; 512

4. Ibidem.

Charaksamhita(4),Santarpaniya Adhyaya, 23/3-4;122

5. Ibidem.

Charaksamhita(5),Santarpaniya Adhyaya, 23/27-29;123

6. Ibidem.

Charaksamhita(6),Santarpaniya Adhyaya, 23/5-7and 22-25;122 and 123

7. Ibidem.

Charaksamhita(7),Vividhashitapiti ya Adhyaya, 28/15;179
8. https://www.niddk.nih.gov/healthinformation/diabetes/overview/wha t-is-diabetes/prediabetes-insulinresistance

9. Madhavakara, Madhukosha, Mahavnidan Pramehanidan Adhyaya 33/5-6, edited by Jadavji Tricumji Acharya., Reprint edition, Chaukhambha Orientalia Varanasi,2010;217-218

10. Susrut, Dalhanacharya, Susrut Samhita, Nidan Sthana, Pramehanidan Adhyaya 6/22 edited by Jadavji Trikamji Acharya.,reprint edition, Chaukhambha Surabharati Prakashan,2012;293

11. Alberti KG, Eckel RH, Grundy $\mathrm{SM}$, et al. Harmonizing the metabolic syndrome: a joint interim statement of the International Diabetes Federation Task Force on Epidemiology and Prevention; National Heart, Lung, and Blood Institute; American Heart Association; World Heart Federation; International Atherosclerosis Society; and International Association for the Study of Obesity. Circulation. 2009;120:1640-1645

https://www.niddk.nih.gov/healthinformation/diabetes/overview/wha t-is-diabetes/prediabetes-insulinresistance

12. Madhavakara, Madhukosha, Mahavnidan Pramehanidan Adhyaya,33/23, edited by Jadavji Tricumji Acharya., Reprint edition, Chaukhambha Orientalia Varanasi, 2010;222

13. Aghnivesh,Charak, Dridhabala, Chakrapanidatta, Charakasamhita, Nidan Sthana, Pramehanidan 4/4, 
edited by Jadavji Trikamji Acharya., Reprint edition, Chaukhambha Surabharati Prakashan Varansi,1992;212

14. NATURE AND NURTURE IN DIABETES: A GENETICIST'S PERSPECTIVE ABOUT THE YOGIC APPROACH, Dr C R SRIKUMARI SRISAILAPATHY1 PhD UGC Research Scientist C, Department of Genetics, PG Institute of Basic Medical Sciences, Taramani Campus ,University of Madras, Chennai 600113, India. Email: crsrikumari@gmail.com

15. ROLE OF YOGA IN PREVENTION AND MANAGEMENT OF DIABETES MELLITUS 1 \& 2 March 2011 Organized by Advanced Centre for Yoga Therapy, Education \& Research, (ACYTER) \& Department of Physiology, JIPMER, Puducherry in collaboration with Morarji Desai National Institute of Yoga (MDNIY), New Delhi (An autonomous organisation under Department of AYUSH, Ministry of Health and Family Welfare, Government of India, New Delhi)

16. A REVIEW OF RESEARCH STUDIES ON YOGA AND DIABETES Dr B K SAHAY MD 1 Eminent diabetologist and past president API. Former Professor of Medicine Osmania Medical College and Chief Investigator Diabetes and Yoga Project, Vimana Yoga Research Institute, Hyderabad

17. HOW OBESITY LEADS TO TYPE 2 DIABETES: A
PHYSIOLOGICAL

EXPLANATION Dr V.

SRINIVASAN MD 1 Director-

Professor (Retd.) Dept. of

Physiology, JIPMER, Pondicherry.

18. Aghnivesh,Charak, Dridhabala, Chakrapanidatta, Charakasamhita, Chikitsa Sthana, Pramehchikitsitam 6/4, edited by Jadavji Trikamji Acharya., Reprint edition, Chaukhambha Surabharati Prakashan Varansi,1992;445

19. Ibidem.

Charaksamhita(19),Pramehanidan Adhyaya, 4/51; 215

20. Susrut, Dalhanacharya, Susrut Samhita, Nidan Sthana, Pramehanidan Adhyaya 6/3 edited by Jadavji Trikamji Acharya., reprint edition, Chaukhambha Surabharati Prakashan,2012;289

21. https://www.niddk.nih.gov/healthinformation/diabetes/overview/wha t-is-diabetes/ prediabetes-insulinresistance

22. NATURE AND NURTURE IN DIABETES: A GENETICIST'S PERSPECTIVE ABOUT THE YOGIC APPROACH, Dr C R SRIKUMARI SRISAILAPATHY1 PhD UGC Research Scientist C, Department of Genetics, PG Institute of Basic Medical Sciences, Taramani Campus ,University of Madras, Chennai 600113, India. Email: crsrikumari@gmail.com

23. Susrut, Dalhanacharya, Susrut Samhita, Chikitsa Sthana, Pramehachikitsa Adhyaya 11/4 edited by Jadavji Trikamji Acharya.,reprint edition, Chaukhambha Surabharati

Prakashan,2012;451 
24. Aghnivesh,Charak, Dridhabala, Chakrapanidatta, Charakasamhita, Chikitsa Sthana, Pramehchikitsitam 6/51, edited by Jadavji Trikamji Acharya., Reprint edition, Chaukhambha Surabharati Prakashan Varansi, 1992;448

25. Ibidem.

Charaksamhita(19),Pramehachikits itam Adhyaya, 6/53; 449

26. International Journal of Yoga and Allied Sciences (ISSN: 2278 5159) Volume: 1, Issue: $168 \mathrm{~A}$ STUDY ON THE EFFECT OF YOGIC INTERVENTION ON SERUM GLUCOSE LEVEL ON DIABETICS, Dr Kamakhya Kumar* *School of Yoga \& Health, Dev Sanskriti Vishwavidyalaya. Haridwar 249411 (India)

27. Ref: Williams \& Wilkins American College of Sport Medicine, ACSM's Resource Manual for Guidelines for exercise testing and prescription, 4th edn, (New York: Lippincott) 2001.
28. https://www.niddk.nih.gov/healthinformation/diabetes/overview/wha t-is-diabetes/prediabetes-insulinresistance

29. AN INNOVATIVE THERAPEUTIC APPROACH TOWARDS DIABETES, Dr. PRAKASH CHINTAMANI MALSHE MD

1 Antar Prakash Centre for Yoga, SF 19, 20 Surya Complex, Ranipur Mode, Haridwar 249407. Mob +919412073252, e-mail: prakashmalshe@rediffmail.com

30. Aghnivesh,Charak, Dridhabala, Chakrapanidatta, Charakasamhita, Sutra Sthana, Yajjapurushiya 25/40, edited by Jadavji Trikamji Acharya., Reprint edition, Chaukhambha Surabharati Prakashan Varansi,1992;132

31. Ibidem.

Charaksamhita(19),Pramehachikits itam Adhyaya, 6/57; 449

32. Ibidem.

Charaksamhita(19),Pramehanidan

Adhyaya, 4/52; 215

Cite article:

Role of vikarvighatbhava and vikarvighatabhava in manifestation of diabetes Goray Namrata Prakash, Harit Maheshkumar, Vinay Pawar

Ayurlog: National Journal of Research in Ayurved Science- 2019; (7)(1): 1-13 